\title{
Study of the density of ganglion cells in the terminal bowel of rats with anorectal malformations ${ }^{1}$
}

\author{
Estudo da densidade das células ganglionares no intestino terminal de ratos \\ portadores de anomalia anorretal
}

\author{
Maurício Macedon ${ }^{2}$, José Luiz Martinss ${ }^{3}$, Karine Furtado Meyer², Iberê Cauduro Soares ${ }^{4}$ \\ 1. Research performed at Department of Surgery, Federal University of São Paulo (UNIFESP), Brazil. \\ 2. Fellow PhD degree, Post-Graduate Program in Experimental Surgery, UNIFESP, Brazil. \\ 3. Associate Professor, Division of Pediatric Surgery, Department of Surgery, UNIFESP, Brazil. \\ 4. MD, Pathologist, Public Servants' Hospital of São Paulo (HSPE), Brazil.
}

\begin{abstract}
Purpose: To study the ganglion cells (GC) in the terminal bowel of rats with ethylenethiourea (ETU) induced anorectal malformations (ARM). Methods: The animals were divided into three groups: Group A - normal fetuses from pregnant rats that were not administered ETU; Group B - fetuses without ARM born from pregnant rats that were administered ETU and Group C - fetuses with ARM born from pregnant rats that received ETU. ETU was administered on the $11^{\text {th }}$ day of pregnancy at the dose of $125 \mathrm{mg} / \mathrm{kg}$ body weight by gastric gavage. The rats had cesarean section on the $21^{\text {st }}$ day of gestation. The fetuses' terminal bowel tissue was analyzed by immunohistochemistry to demonstrate ganglion cells. Results: Statistically significant differences were found between groups A, B and C regarding ganglion cell densities. Group A had the highest cell density, followed by Group B and the lowest density was found in Group C. Conclusion: Ganglion cell densities are decreased in the terminal bowel of rats with ARM.
\end{abstract}

Key words: Anus, Imperforate. Constipation. Ethylenethiourea. S100 protein. Enteric Nervous System. Rats.

\section{RESUMO}

Objetivo: Estudar as células ganglionares (CG) no intestino terminal de ratos portadores de anomalia anorretal (AAR) induzida pela etilenotiouréia (ETU). Métodos: Os animais foram distribuídos em três grupos: Grupo A - fetos normais, obtidos de ratas grávidas às quais não foi administrada ETU; Grupo B - fetos não portadores de AAR obtidos de ratas grávidas às quais foi administrada ETU e Grupo $\mathrm{C}$ - fetos portadores de AAR obtidos de ratas grávidas às quais foi administrada ETU. A ETU foi administrada no décimo primeiro dia de gestação na dose de $125 \mathrm{mg} / \mathrm{Kg}$, por gavagem. As ratas foram submetidas à laparotomia e histerotomia para retirada dos fetos no vigésimo primeiro dia de gestação. O intestino terminal dos fetos foi retirado e analisado por imunohistoquímica para pesquisa de CG. Resultados: Foram encontradas diferenças estatisticamente significantes entre os grupos $\mathrm{A}, \mathrm{B}$ e $\mathrm{C}$ quanto à densidade de $\mathrm{CG}$. $\mathrm{O}$ grupo $\mathrm{A}$ apresentou a maior densidade, seguida pelo grupo B, e a menor densidade foi encontrada no Grupo C. Conclusão: Existe uma menor densidade de CG no intestino terminal de ratos portadores de AAR.

Descritores: Anus Imperfurado. Constipação Intestinal. Etilenotiouréia. Proteínas S100. Sistema nervoso entérico. Ratos. 


\section{Introduction}

Intestinal constipation is one of the most frequent complaints in the postoperative period of correction of anorectal malformation (ARM), occurring in 30\% to $60 \%$ of patients ${ }^{1,2}$. It is a symptom that must be aggressively treated since it may trigger a picture of pseudoincontinence ${ }^{1,5}$. In the vast majority of cases, good results can be obtained with diet, oral laxatives and enema. Occasionally, constipation presents an intense and progressive character that is unresponsive to usual therapeutic measures. These patients usually present extremely dilated, atonic and ectasic rectum and sigmoid in association with deficient propulsive function ${ }^{1,4-6}$. The possible causes to explain intestinal constipation in the postoperative period of ARM include: anal stenosis ${ }^{3}$, abnormalities of extrinsic intestinal innervation ${ }^{7}$ and rectal denervation during the surgical procedure ${ }^{8}$. Constipation may also be attributed to regional changes in intrinsic intestinal innervation (III), and there are reports abnormalities in ganglion cells (GC) of myenteric and submucous plexuses. Such changes include aganglionosis, hypoganglionosis and intestinal neuronal dysplasia ${ }^{9-12}$. The study of the III can be performed as follows: by conventional histology using the classic hematoxylin-eosin staining 13; enzyme histochemical methods, such as activity of acetylcholinesterase, lactate dehydrogenase, succinate dehydrogenase and nitric oxide synthetase ${ }^{13}$; and by immunohistochemical methods. Staining for GC or for neuronal supportive cells, also known as neuroglial cells, may be used in immunohistochemistry. For neuroglial cells, S-100 protein and glial fibrillary acidic protein (GFAP) ${ }^{14-15}$ reactions may be used; and for GC staining, neuron-specific enolase and neurofilament protein reactions ${ }^{14}$. The aim of this research is the comparative study of GC density in the terminal intestine of normal rats and rats with ARM induced by ethylenethiourea (ETU) ${ }^{16}$, using S-100 protein reaction.

\section{Methods}

Six female WISTAR rats, weight 241-260 grams, were used. After an one-night mating, animals that presented a vaginal smear test positive for sperm in the next morning were considered fertilized. This was considered day zero (D0) of pregnancy. Animals were kept in individual cages and received commercial feed and water ad libitum, in an environment with constant temperature and humidity and automatically controlled 12-hour daytime and night cycles. On the $11^{\text {th }}$ day (D11) of pregnancy, three pregnant rats received $125 \mathrm{mg} / \mathrm{KgETU}$ (2-imidazolidinethioneC3H6N2S $98 \%$, batch number 24251-089, Sigma-Aldrich, Brazil) by gavage and diluted with distilled water in a concentration of $1 \%(12.5 \mathrm{ml} / \mathrm{Kg})$. The other three rats received only distilled water $(12.5 \mathrm{ml} / \mathrm{Kg})$ with no ethylenethiourea. The rats underwent cesarean section on the $21^{\text {st }}$ (D21) day of pregnancy with removal of fetuses. Fetuses were examined for sex determination and assessment of the presence of ARM and other malformations. The model used caused anorectal anomaly in $72 \%$ of fetuses of rats treated with ETU. No fetus from rats untreated with ETU presented malformations. The animals were then divided into three groups:

Group external control (A) ( $\mathrm{N}=11)$ - Normal fetuses, obtained from rats untreated with ETU;

Group internal control (B) $(\mathrm{N}=8)$ - Fetuses without ARM obtained from rats treated with ETU;

Group anorectal malformation $(\mathrm{C})(\mathrm{N}=21)-$ Fetuses with ARM, obtained from rats treated with ETU.

Afterwards, by means of optical microscopy, fetuses underwent exploratory laparotomy to determine the type of ARM, when present, and to excise one centimeter of terminal intestine for immunohistochemical study. In normal fetus, dissection of terminal intestine was performed up to the anal level, and in fetuses with ARM it was carried out up to the fistula site. The one-centimeter fragment of terminal intestine was fixed in $10 \%$ buffered formaldehyde, dehydrated and embedded in paraffin. The types of anorectal malformation found were: 13 cases of cloacal malformation, 4 ARM with perineal fistula and 4 ARM with urethral fistula.

\section{Immunohistochemistry}

From the previously paraffin-embedded material, three-micron sections were performed in the intestinal longitudinal axis and the sections were processed with the streptavidin-biotin-peroxidase technique. The sequence of immunohistochemical procedures included deparaffination in stove, deparaffination in xylol, rehydration in absolute alcohol, antigen recovery with $0.01 \mathrm{M}$ citrate buffer at $\mathrm{pH}$ 6.0, block of endogenous peroxidase activity with a solution of hydrogen peroxide $\left(\mathrm{H}_{2} \mathrm{O}_{2}\right)$, block of inespecific reaction through incubation with a phosphate buffer at $\mathrm{pH} 7.2$, with addition of $1 \%$ bovine serum albumin for 15 minutes, incubation in the primary antibody against S-100 protein at the dilution of 1:2000 (Rabbit Polyclonal Antibody NCL-S100p-Novocastra) overnight, at approximately $8^{\circ} \mathrm{C}\left(46.4^{\circ} \mathrm{F}\right)$, incubation in a biotinylated secondary antibody at room temperature for 30 minutes, incubation in the streptavidin-biotin-peroxidase complex at room temperature for 30 minutes, incubation with enzyme substrate diaminobenzidine and counterstaining with Harris hematoxylin.

\section{Ganglion cells count}

Each fetus was represented by a slide of terminal intestine magnified 400 times, and ten digital images were 
obtained throughout the intestine with the use of a Sony ${ }^{\circledR}$ CCD-IRIS video camera attached to an Olympus (BX 50) light microscope. The images obtained were studied with a program of image analysis called "Image Tool" ( - version 3.0. For each image obtained, we calculated the area corresponding to the circular and longitudinal musculature and counted the number of GC in the isolated area. Cellular density was obtained by the total number of cells divided by the total area, thus yielding the number of cells per $\mathrm{mm}^{2}$.

\section{Analyses performed}

We compared the densities of GC in the terminal intestine of fetuses from the three groups by using analysis of variance (ANOVA) and the Bonferroni method. The significance level used was $0.05(\alpha=5 \%)$ and descriptive levels (p) lower than this value were considered significant.

\section{Ethics}

This experiment received approval from the Research Ethics Committee of the Federal University of São Paulo (UNIFESP-EPM - protocol n. 0406/05).

\section{Results}

The density of GC in animals of the three groups is shown in Table 1. Statistically significant differences were found in the three groups regarding GC density in the terminal intestine, when submitted to variance analysis (Table 2). Comparing the groups in pairs by the Bonferroni

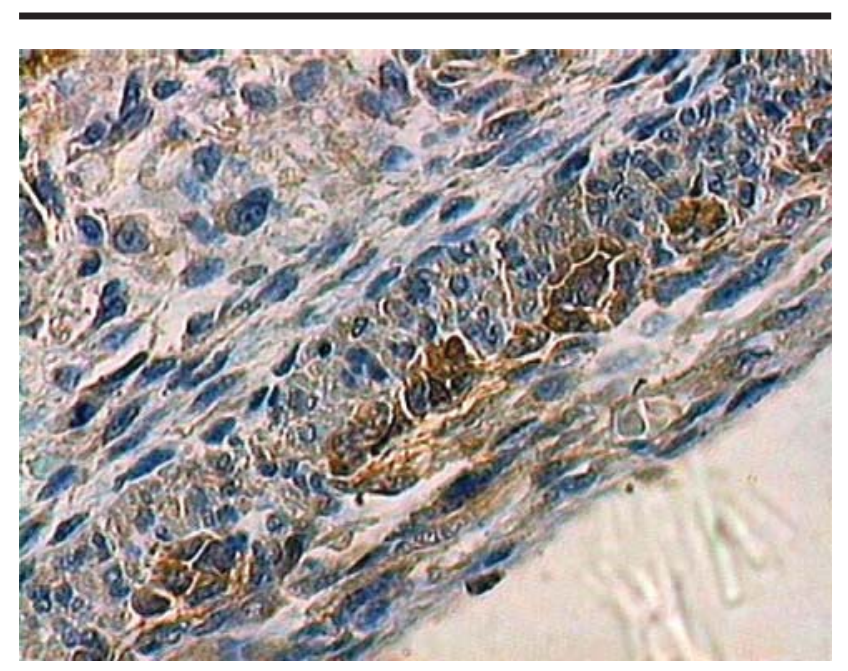

FIGURE 1 - Photomicrography of the terminal intestine of the external control group with S-100 protein staining method, the results showed statistically significant differences among the three groups (Table 3). The external control group presented a higher density than the internal control group, which, in turn, presented higher density than ARM group (Figures 1, 2 and 3).

TABLE 1 - Density of ganglion cells in animals from Groups A, B and C (cells per $\mathrm{mm}^{2}$ )

\begin{tabular}{|c|c|c|}
\hline Group A & Group B & Group C \\
\hline 28,71 & 21,64 & 18,12 \\
\hline 27,10 & 23,02 & 9,95 \\
\hline 26,84 & 17,49 & 17,05 \\
\hline 23,17 & 18,93 & 17,16 \\
\hline 26,08 & 18,43 & 13,34 \\
\hline 24,63 & 17,69 & 14,24 \\
\hline 24,07 & 17,16 & 11,34 \\
\hline 21,83 & 20,56 & 12,29 \\
\hline 33,70 & & 10,10 \\
\hline 29,00 & & 8,77 \\
\hline \multirow[t]{11}{*}{26,47} & & 9,78 \\
\hline & & 11,67 \\
\hline & & 6,55 \\
\hline & & 10,53 \\
\hline & & 8,70 \\
\hline & & 11,75 \\
\hline & & 19,66 \\
\hline & & 15,42 \\
\hline & & 11,82 \\
\hline & & 13,37 \\
\hline & & 11,27 \\
\hline
\end{tabular}

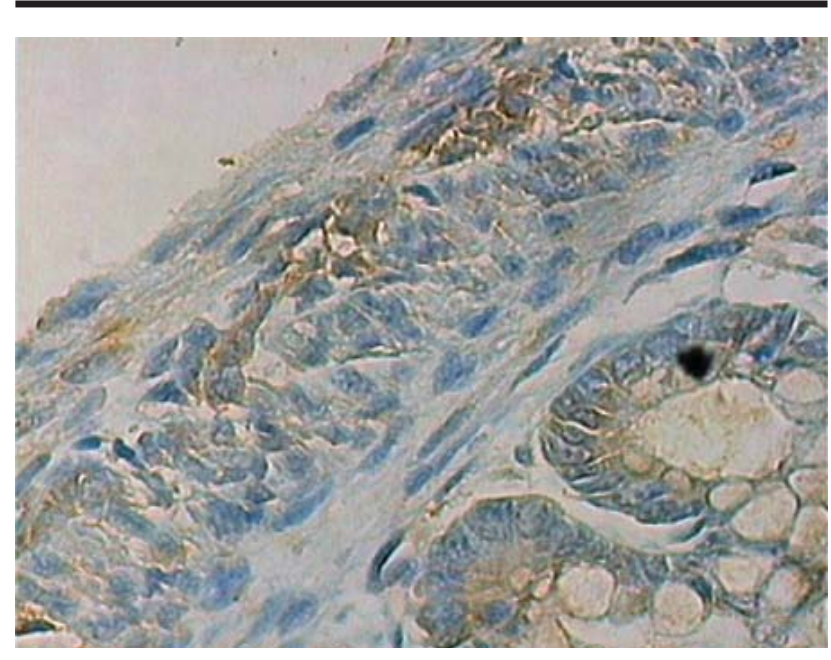

FIGURE 2 - Photomicrography of the terminal intestine of the internal control group with S-100 protein staining 
TABLE 2 - Description of the variable "Density of ganglion cells" in groups A, B e C

\begin{tabular}{lcccc}
\hline & \multicolumn{4}{c}{ Density of ganglion cells/mm ${ }^{2}$} \\
\cline { 2 - 5 } Group & $\mathrm{N}$ & Mean \pm S.D. & Median & Minimum-Maximum \\
\hline Group A & 11 & $26,51 \pm 3,25$ & 26,47 & $21,83-33,70$ \\
Group B & 8 & $19,36 \pm 2,15$ & 18,68 & $17,16-23,02$ \\
Group C & 21 & $12,52 \pm 3,39$ & 11,75 & $6,55-19,66$ \\
\hline \multicolumn{5}{c}{$\mathrm{p}<0,001$} \\
& F Test (ANOVA)
\end{tabular}

Key:

$\mathrm{N}-$ Number

$\mathrm{SD}$ - Standard deviation

$\mathrm{mm} 2$ - Square millimeter

TABLE 3 - Multiple comparisons among Groups A, B and C, for the variable "Density of ganglion cells"

\begin{tabular}{lccc}
\hline Variable & Mean difference & $\mathrm{p}$ & Conclusion \\
\hline Group A - Group C & 13,9 & $<0,001$ & Group A > Group C \\
Group A - Gr oup B & 7,1 & $<0,001$ & Group A > Group B \\
Group B - Group C & 6,8 & $<0,001$ & Group B > Group C \\
\hline
\end{tabular}

Bonferroni Method

$\mathrm{p}<0,05$



FIGURE 3 - Photomicrography of the terminal intestine of the ARM group with S-100 protein staining

\section{Discussion}

The occurrence of III abnormalities in ARM is a controversial issue among some authors, who have been always concerned about investigating the presence or absence of GC in biopsies or in surgical resections. In reports mentioned above ${ }^{4-6}$, no abnormalities were found. Other authors, however, described different results. Parkkulainen et al ${ }^{9}$ evaluated the presence of ganglia in 25 ARM individuals, and found aganglionosis in 15 (60\%). Kiesewetter et al ${ }^{10}$ conducted a study involving 32 pediatric surgery centers in the United States and Canada, in which 296 patients were assessed and 10 (3.4\%) presented aganglionosis. Holschneider et $\mathrm{al}^{11}$ studied 52 patients and observed an abnormal innervation pattern in 49 (94\%). Meier-Ruge et al ${ }^{12,17}$ evaluated 41 ARM patients and observed $60 \%$ of enteric nervous system anomalies. Anyway, considering that the incidence of ARM, as well as that of aganglionosis, is one in 5000 newborns, it would be expected to find an even lower frequency for the association of both lesions than for the conditions isolated. The current study evaluated the intrinsic intestinal innervation through the study of GC. This study involved the calculation of cell density per square millimeter in the area represented by the circular and longitudinal muscular layers where the myenteric plexus is located and already present in the newborn rat. The S-100-protein immunohistochemical method was chosen because the enteric glial cells and the Schwann cells in the intestine presented strong immunoreactivity for this protein with a significant visualization of the GC supportive elements 13,15. Harris hematoxylin counterstaining was associated for GC staining. Experimental studies correlating ARM with intrinsic intestinal innervation are scarce and applied different methods. Favre et al ${ }^{18}$ used neurofilament protein and nitric oxide synthetase stainings in Danforth's short tail mice and demonstrated an association with hypoganglionosis (41\%) andaganglionosis(58\%). Mandhan et al ${ }^{19}$ used neuron-specific enolase and P-substance to assess the terminal intestine of newborn rats with ARM induced by ETU, and reported decreased immunoreactivity in both methods. The internal control group, despite not having ARM in its phenotype, presented a decreased count of GC. This fact might be related to the mechanism of action of ETU. It is believed that ETU possibly has its effects by changing the signaling of the Sonic hedgehog (SHH) gene. The molecule codified by the $\mathrm{SHH}$ gene is 
involved in the development of several systems, including the nervous and skeletal systems, craniofacial structures and the gastrointestinal tract. In the gastrointestinal tract, the molecule is responsible for the regionalization of the primitive gut tube, the radial pattern of the digestive tube, the differentiation of its layers and the differentiation of enteric neurons ${ }^{20}$. The abnormalities found in the internal control group might have been triggered by changes in the signaling of $\mathrm{SHH}$ gene, which caused some of the abnormalities found, but it did not have its full effect for not inducing ARM.

\section{Conclusion}

There is a lower ganglion cells density in the terminal intestine of rats with ARM induced by ethylenethiourea.

\section{References}

1. Rintala RJ. Fecal incontinence in anorectal malformations, neuropathy, and miscellaneous conditions. Seminar Pediatr Surg. 2002;11:75-82.

2. Martucciello G, Mazzola C, Favre A, Negri F, Bertagnon M, Morando A, Torre M, Gambini C, Jassonni V. Preoperative enzymo-histochemical diagnosis of dysganglionoses associated with anorectal malformations (ARM) with rectovestibular and recto-perineal fistula. Eur J Pediatr Surg. 1999;9:96-100.

3. Nixon HH, Puri P. The results of treatment of anorectal anomalies: a thirteen to twenty year follow-up. J Pediatr Surg. 1977;12:27-37.

4. Powell RW, Sherman JO, Raffensperger JG. Megarectum: a rare complication of imperforate anus repair and its surgical correction by endorectal pullthrough. J Pediatr Surg. 1982;17:786-95.

5. Peña A, El Behery M. Megasigmoid: A source of pseudoincontinence in children with repaired anorectal malformations. J Pediatr Surg. 1993;28:199-203.

6. Cheu HW, Grosfeld JL. The atonic baggy rectum: a cause of intractable obstipation after imperforate anus repair. J Pediatr Surg. 1992;27:1071-4.

7. Macedo M, Martins JL, Freitas-Filho LG. Sacral Ratio and fecal continence in children with anorectal malformations. BJU Int. 2004;94:893-4.
8. Rintala R, Lindahl H, Sariola H, Rapola J, Louhimo I. The rectourogrnital connection in anorectal malformations is an ectopic anal canal. J Pediatr Surg. 1990;25:665-8.

9. Parkkulainen KV, Hjelt L, Sulamaa M. Anal atresia combined with aganglionic megacolon. Acta Chir Scan. 1959;118:252-6.

10.Kiesewetter WB, Sukarochana K, Sieber WK. The frequency of aganglionosis associated with imperforate anus. Surgery. $1965 ; 58: 877-80$

11.Holschneider AM, Ure BM, Pirommer W, Méier-Ruge W. Innervation patterns of the rectal pouch and fistula in anorectal malformations: a preliminary report. J Pediatr Surg. 1996;31:357-62.

12.Meier-Ruge WA, Holschneider AM. Histopathologic observations of anorectal abnormalities in anal atresia. Pediatr Surg Int. 2000;16:2-7

13.Mackenzie JM, Dixon MF. An immunohistochemical study of the enteric neural plexi in Hirschsprung's disease. Histopathology. 1987;11:1055-66.

14.Kato H, Yamamoto T, Yamamoto H, Ohi R, So N, Iwasaki Y. Immunocytochemical characterization of supporting cells in the enteric nervous system in Hirschsprung's disease. J Pediatr Surg. 1990;25:514-9.

15.Ferri GL, Probert L, Cocchia D, Michetti F, Marangos PJ, Polak JM. Evidence for the presence of S-100 protein in the glial component of the human enteric nervous system. Nature. 1982;297:409-10.

16. Macedo M, Martins JL, Meyer KM. Evaluation of an experimental model for anorectal anomalies induced by ethylenethiourea. Acta Cir Bras. 2007;22(2):130-6.

17.Meier-Ruge WA, Bruder E. Anorectal irregularities in anal atresia. Pathobiology. 2005;72:59-62.

18.Favre A, Briano S, Mazzola C, Brizzolara A, Torre M, Cilli M, Sanguineti M Martuciello G. Anorectal malformations associated with enteric dysganglioosis in Danforth's short tail (sd) mice. J Pediatr Surg. 1999;34:1818-21.

19.Mandhan P, Qui QB, Beasley SW. Aberrations of the intrinsic innervation of the anorectum in fetal rats with anorectal malformations. J Pediatr Surg. 2005;40:397-402.

20.Sukegawa A, Narita T, Kameda T, Saitoh K, Nohno T, Iba H, Yasugi S, Fukuda K. The concentric structure of the developing gut is regulated by sonic hedgehog derived from endodermal epithelium. Development. 2000:127:1971-80.

\section{Correspondence:}

Maurício Macedo

Rua Comandante Garcia D’ Ávila, 37

05654-040 São Paulo - SP Brazil

Phones: (55 11)3772-4594 / 7152-2726

mmmacedo@uol.com.br
Conflict of interest: none

Financial source: FAPESP n.05/56062-8.

Received: April 10, 2007

Review: June 12, 2007

Accepted: July 18, 2007

\section{How to cite this article}

Macedo M, Martins JL, Meyer KF, Soares IC. Study of the density of ganglion cells in the terminal bowel of rats with anorectal malformations. Acta Cir Bras. [serial on the Internet] 2007 Nov-Dec;22(6). Available from URL: http://www.scielo.br/acb 